\title{
Adult hemimegalencephaly associated with multiple cerebral aneurysms
}

Figure 1 T2-weighted MRIs showing an increase in the right hemispheric volume (A) and enlargement of the right lateral ventricle (B)
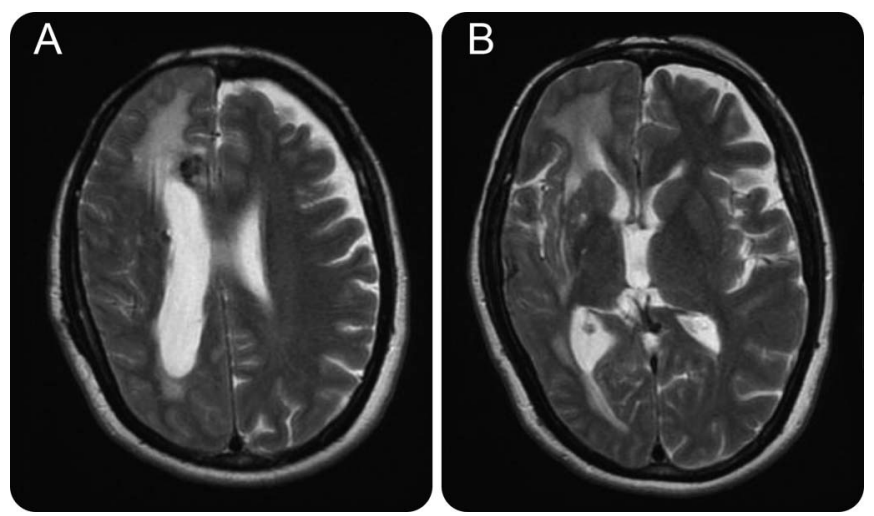

A 45-year-old woman with normal physical and mental development, who had intractable epilepsy since her childhood, had neither cognitive nor neurologic deficits. Her MRI demonstrated right hemimegalencephaly (HME) with an increase in the hemispheric volume and enlargement of the right lateral ventricle (figure 1),

Figure 2 Cerebral angiography of right $(A, C)$ and left $(B, D)$ internal carotid arteries showing multiple cerebral aneurysms of fusiform type (arrowheads) in the right hemisphere

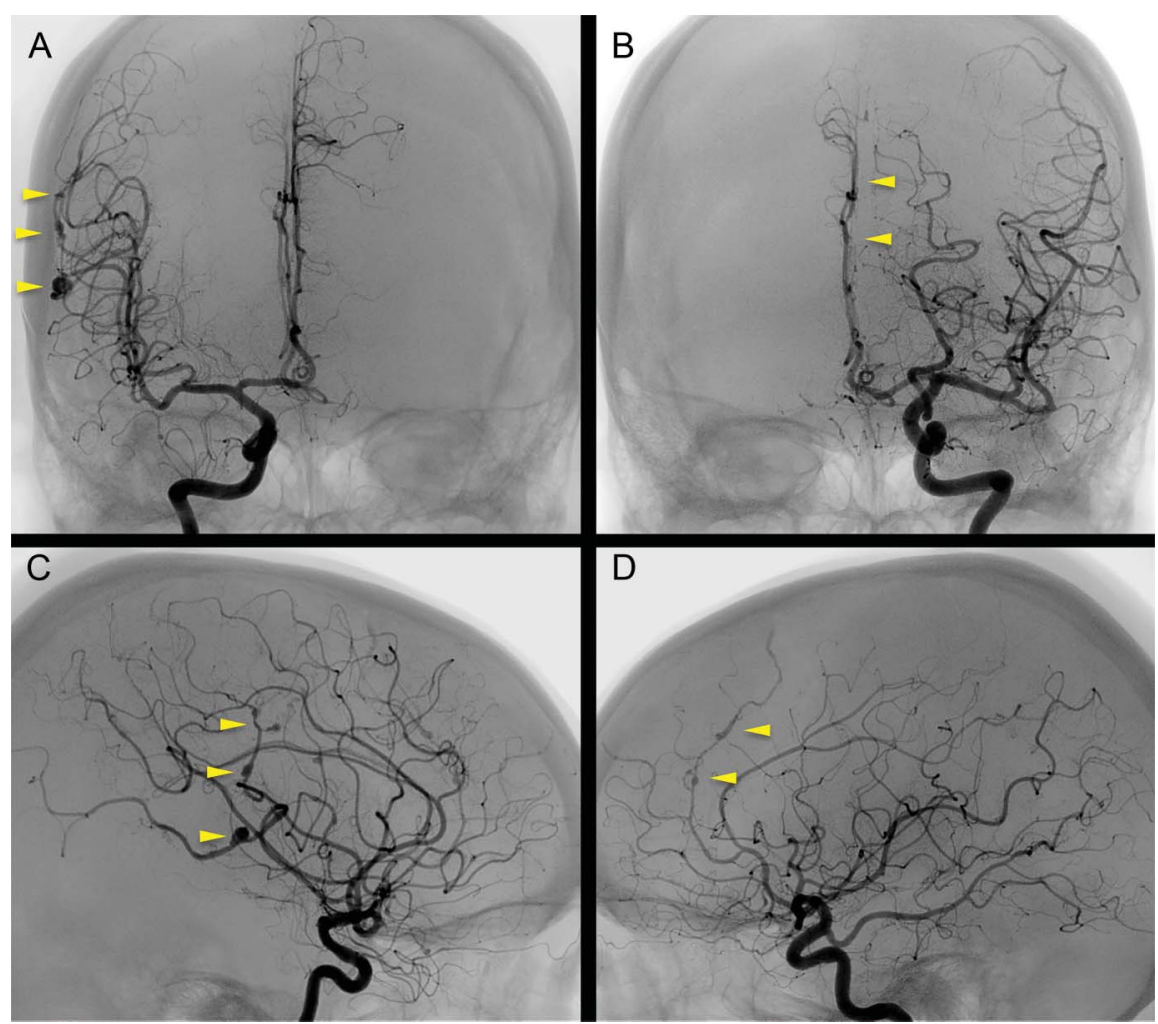


and dilated arteries. Her angiography confirmed multiple cerebral fusiform aneurysms in the periphery of the right anterior and middle cerebral arteries (figure 2).

HME is reported to be an abnormality in neuronal/glial development/proliferation with diverse gene mutations. ${ }^{1}$ Although its association with venous abnormalities has been reported, ${ }^{2}$ its association with aneurysms has never been reported.

Harubiko Kishima, MD, PhD, Hajime Nakamura, MD, PhD, Satoru Oshino, MD, PhD,

Hisashi Tanaka, MD, PhD, Toshiki Yoshimine, MD, PhD

From the Departments of Neurosurgery (H.K., H.N., S.O., T.Y.) and Radiology (H.T.), Osaka University Graduate School of Medicine, Epilepsy Center, Osaka University Hospital, Japan.

Author contributions: Dr. Kishima: study concept and drafting the manuscript for intellectual content. Dr. Nakamura: revision of the manuscript for intellectual content. Dr. Oshino: revision of the manuscript for intellectual content. Dr. Tanaka: revision of the manuscript for intellectual content. Dr. Yoshimine: study supervision.

Study funding: No targeted funding reported.

Disclosure: H. Kishima is funded by Grants-in-Aid for Scientific Research (T26462207) from the Ministry of Education, Culture, Sports, Science and Technology of Japan and Grants-in-Aid for Scientific Research (KH24AB004a) from the Ministry of Health, Labor and Welfare of Japan. H. Nakamura reports no disclosures relevant to the manuscript. S. Oshino is funded by Grants-in-Aid for Scientific Research (T26462208) from the Ministry of Education, Culture, Sports, Science and Technology of Japan. H. Tanaka is funded by Grants-in-Aid for Scientific Research (T25461821) from the Ministry of Education, Culture, Sports, Science and Technology of Japan. T. Yoshimine served as an editorial board member of Neurologia medico-chirurgica and is funded by the Strategic Research Program for Brain Sciences, Translational Research Network Program, and Grants-in-Aid for Scientific Research (T22390275) from the Ministry of Education, Culture, Sports, Science and Technology of Japan. Go to Neurology.org for full disclosures.

Correspondence to Dr. Kishima: hkishima@nsurg.med.osaka-u.ac.jp

1. Poduri A, Evrony GD, Cai X, et al. Somatic activation of AKT3 causes hemispheric developmental brain malformations. Neuron 2012;74:41-48.

2. Sato N, Yagishita A, Oba H, et al. Hemimegalencephaly: a study of abnormalities occurring outside the involved hemisphere. AJNR Am J Neuroradiol 2007;28:678-682.

\section{Visit the Neurology ${ }^{\circledR}$ Web Site at Neurology.org}

- Enhanced navigation format

- Increased search capability

- Highlighted articles

- Detailed podcast descriptions

- RSS Feeds of current issue and podcasts

- Personal folders for articles and searches

- Mobile device download link

- AAN Web page links

- Links to Neurology Now ${ }^{\circledR}$, Neurology Today ${ }^{\circledR}$, and Continuum ${ }^{\circledR}$

- Resident \& Fellow subsite

(A) Find Neurology ${ }^{\circledR}$ on Facebook: http://tinyurl.com/neurologyfan

twitter Follow Neurology ${ }^{\circledR}$ on Twitter: https://twitter.com/GreenJournal 


\section{Neurology}

\section{Adult hemimegalencephaly associated with multiple cerebral aneurysms \\ Haruhiko Kishima, Hajime Nakamura, Satoru Oshino, et al.}

Neurology 2015;84;2460-2461

DOI 10.1212/WNL.0000000000001685

This information is current as of June 15, 2015

\begin{tabular}{|c|c|}
\hline $\begin{array}{l}\text { Updated Information \& } \\
\text { Services }\end{array}$ & $\begin{array}{l}\text { including high resolution figures, can be found at: } \\
\text { http://n.neurology.org/content/84/24/2460.full }\end{array}$ \\
\hline References & $\begin{array}{l}\text { This article cites } 2 \text { articles, } 0 \text { of which you can access for free at: } \\
\text { http://n.neurology.org/content/84/24/2460.full\#ref-list-1 }\end{array}$ \\
\hline Subspecialty Collections & $\begin{array}{l}\text { This article, along with others on similar topics, appears in the } \\
\text { following collection(s): } \\
\text { All Cerebrovascular disease/Stroke } \\
\text { http://n.neurology.org/cgi/collection/all_cerebrovascular_disease_strok } \\
\text { e } \\
\text { All Epilepsy/Seizures } \\
\text { http://n.neurology.org/cgi/collection/all_epilepsy_seizures } \\
\text { Cortical dysplasia } \\
\text { http://n.neurology.org/cgi/collection/cortical_dysplasia } \\
\text { MRI } \\
\text { http://n.neurology.org/cgi/collection/mri }\end{array}$ \\
\hline Permissions \& Licensing & $\begin{array}{l}\text { Information about reproducing this article in parts (figures,tables) or in } \\
\text { its entirety can be found online at: } \\
\text { http://www.neurology.org/about/about_the_journal\#permissions }\end{array}$ \\
\hline Reprints & $\begin{array}{l}\text { Information about ordering reprints can be found online: } \\
\text { http://n.neurology.org/subscribers/advertise }\end{array}$ \\
\hline
\end{tabular}

Neurology ${ }^{\circledR}$ is the official journal of the American Academy of Neurology. Published continuously since 1951, it is now a weekly with 48 issues per year. Copyright @ 2015 American Academy of Neurology. All rights reserved. Print ISSN: 0028-3878. Online ISSN: 1526-632X.

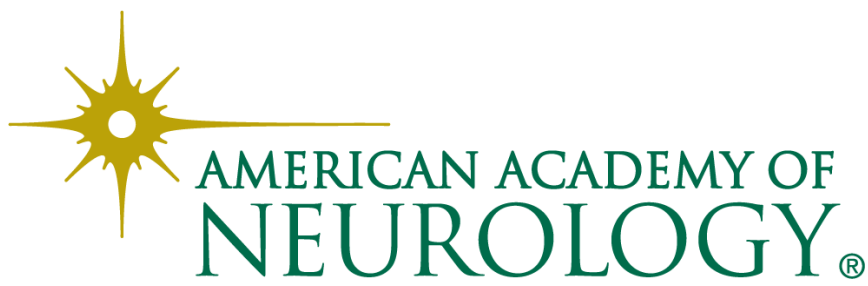

